\title{
Article \\ Determinants of Tax Compliance Intention among Jordanian SMEs: A Focus on the Theory of Planned Behavior
}

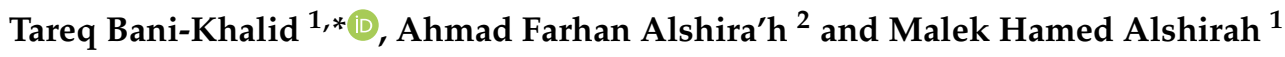 \\ 1 Accounting Department, School of Business, Al al-Bayt University, Al-Mafraq 130040, Jordan; \\ shraamalek@gmail.com \\ 2 Accounting Department, Faculty of Administrative and Financial Sciences, Irbid National University, \\ Irbid 2600, Jordan; alshraah.ahmad@yahoo.com \\ * Correspondence: tareq_alkhaldi@aabu.edu.jo
}

Citation: Bani-Khalid, Tareq, Ahmad Farhan Alshira'h, and Malek Hamed Alshirah. 2022. Determinants of Tax Compliance Intention among Jordanian SMEs: A Focus on the Theory of Planned Behavior. Economies 10: 30. https://doi.org/ 10.3390/economies10020030

Academic Editor: Ralf Fendel

Received: 16 November 2021

Accepted: 4 January 2022

Published: 26 January 2022

Publisher's Note: MDPI stays neutral with regard to jurisdictional claims in published maps and institutional affiliations.

Copyright: (C) 2022 by the authors. Licensee MDPI, Basel, Switzerland. This article is an open access article distributed under the terms and conditions of the Creative Commons Attribution (CC BY) license (https:// creativecommons.org/licenses/by/ $4.0 /)$.

\begin{abstract}
The present study aimed to adopt the extended theory of planned behavior (TPB) to determine the intentions of owner-managers in SMEs towards engaging in sales tax compliance. The study distributed a total of 660 questionnaire copies through systematic random sampling to the mangers/owners of Jordanian manufacturing SMEs, from which 385 questionnaire copies were retrieved and considered useable and appropriate for further analysis. The study made use of PartialLeast Squares-Structural Equation Modeling (PLS-SEM) for the validation of the measurement model and structural model, and to establish the predictive relevance of the proposed model. Based on the obtained findings, the attitude towards behavior, subjective norms, perceived behavioral control and patriotism were significant determinants of the intentions towards engaging in sales tax compliance among the examined enterprises.
\end{abstract}

Keywords: attitudes; subjective norms; perceived behavioral control; patriotism; sales tax compliance

\section{Introduction}

In the developing nations, considerable challenges are faced in light of increasing tax revenues for the purpose of financing their developmental requirements (Besley and Persson 2014). Evading taxes leads to economic costs, slowing down the growth of the economy and mitigating the ability of the government to furnish sufficient goods and services to the public (Alshira'h 2019; Randlane 2016). In other words, tax evasion is among the main issues that the developing nations have been facing (Alshira'h et al. 2020a; Fuest and Riedel 2009). Therefore, policy makers need to determine the causes behind tax compliance in order to carry out reforms and minimize the negative effects of evasion all around the globe (Achek 2015; Alshira'h and Abdul-Jabbar 2019a). This involves understanding and determining the causal factors behind tax compliance, as evidenced by the interests of the majority of scholars throughout the past decades (Alshira' $h$ and Abdul-Jabbar 2020; Yucedogru and Hasseldine 2016). Tax compliance at the business level has not been extensively examined, although the majority of the bulk of taxes in countries are obtained from firms, with the firms constituting a significant portion of tax evaders (Alshira'h et al. 2020b; Carsamer and Abbam 2020).

Notably, the tax compliance issue has long been discussed among economists, who have proposed models to clarify the reason behind tax non-compliance (Alshira'h et al. 2019; Ya'u et al. 2020). Despite the fact that the proposed models' purpose is to shed light on the reasons behind the evasion of taxpayers, they are still unable to completely explain the phenomenon because they exclude socio-psychological variables. The majority of nations all over the globe have high tax compliance in the face of low degrees of deterrence (Alshira'h 2018; Torgler 2007). Other relevant studies (Allingham and Sandmo 1972; Yitzhaki 1974) contributed to the literature by proposing theoretical models that distinguish the determinants of tax compliance behavior, which stressed several variables' 
effects. Nevertheless, these models are generally confined to the economic factors of tax non-compliance, as evidenced by the initial models, and they largely ignored the social context (Alshira'h and Abdul-Jabbar 2019a; Molero and Pujol 2012). However, economic factors in the form of penalties, the audit rate and the tax rate, among others, are not the only factors that affect tax compliance according to several studies. Notably, despite the analytical appeal of the economic approach, it mostly misses the realistic and humanistic aspect. All behavioral treatments generally possess a key feature, stating that the values, attitudes, perceptions and morals of economic actors are of key significance, and that evasion is not merely a function of tax rates, opportunity, detection probability and others but also has to do with the evasion/compliance inclination of the individual (Alshira'h et al. 2018; Cullis and Lewis 1997). According to researchers, non-economic factors can shed more light on the issue (Alshir'ah et al. 2016).

More specifically, social factors are significant determinants of tax compliance, as evidenced by Kirchler et al. (2008), and have to be considered when identifying the tax noncompliance determinants (Torgler 2002), particularly as only a few authors have tackled the issue from this point of view.

Moreover, only a few studies have also viewed the issue from the social perspective of socio-psychology, with a study yet to be performed to analyze the Theory of Planned Behavior (TPB) in light of compliance towards sales tax among Arab countries' SMEs, particularly in Jordan. Added to this, prior studies examined the factors that affect intentions towards sales tax compliance engagement by extending the TPB, in which different factors were combined (Alleyne and Harris 2017). In the face of these many studies that extended the TPB, the present study is one of the pioneering ones that expanded the theory through the incorporation of patriotism and its effect on the intention to engage in sales tax compliance among SMEs. Only a few studies of this caliber have been conducted, and were not particularly focused on sales tax. Thus, Alshira'h et al. (2018), Gangl et al. (2016), and MacGregor and Wilkinson (2012) recommended that the effect of patriotism on sales tax compliance be examined among SMEs. This factor should be considered as a priority when it comes to the sales tax compliance of SMEs, particularly in Jordan. Thus, this study answered the call, and tests patriotism effects using the extended TPB to predict intentions towards engaging in sales tax compliance among SMEs in Jordan, a Middle Eastern nation.

As mentioned previously, studies have been carried out to examine income tax compliance, but comparatively, sales tax compliance has largely been ignored (Alshira'h et al. 2020a). Additionally, the majority of the studies dedicated to sales tax compliance in the literature were conducted in developed nations (Alshira'h and Abdul-Jabbar 2019b; Woodward and Tan 2015). Among business enterprises, deductions can be overstated, income can be underreported, or tax returns can remain un-filed, as characteristics of the tax behavior of individuals (Alm et al. 2019). At the same time, sales taxes are riddled with evasion opportunities, with businesses frequently opting to provide fake invoices, enabling the understatement of due tax, or they do not register at all, specifically with high sales tax, as is the case of service providers. Studies dedicated to tax compliance have generally been examined using individual income tax, with the point of view of owner-managers of SMEs in sales tax largely ignored, as was highlighted by Alm et al.'s (2019) study. Furthermore, tax compliance studies among SMEs are still few and far between compared to individual income tax compliance studies, which form a major portion of the literature. According to Abdixhiku et al. (2018), tax non-compliance studies among businesses are lacking, and this is significant because the majority of countries obtain taxes from businesses, with such businesses constituting a major portion of non-compliant entities (Crocker and Slemrod 2005; Nur-Tegin 2008). Hence, this study attempts to minimize the literature gap by contributing to public finance literature. Throughout the past three decades, an increasing shift has been made by industrialized economies in their stress from direct taxation to indirect taxation as a tool to maximize revenues (Wadesango and Chirebvu 2020), specifically sales tax and custom duties. Sales tax is generally called value added tax (VAT) or goods and services tax (GST) all over the globe. In particular, while EU members refer to it as VAT, 
Malaysia, Singapore and Australia prefer to call it GST. The pioneering introduction of VAT was made in France in 1954, as documented by Adams and Webley (2001); in the current times, VAT is used in about 160 nations all over the world (Alshira'h et al. 2021; Azmi et al. 2016; Ramli et al. 2015). Furthermore, Alm and El-Ganainy (2013) indicated that sales tax is the major government revenue source in over 120 nations, involving around four billion people, and it is considered to be effective in light of tax revenue because it garners a high revenue while mitigating deficits (Chan et al. 2017; Lee et al. 2013).

A good example of the above would be the collection of tax revenue through VAT in Brazil, Argentina, Venezuela and Uruguay, constituting 70\%, 65\%, 60\% and 52\%, respectively (Wright et al. 2017). Moreover, VAT has a key role as a budget income source in EU nations, inclusion Portugal, Poland, Greece, Ireland and Hungary, ranging from 40 to $64 \%$ of the total revenues (Dobrowolska 2008). For governments, sales tax is crucial because it provides a tax revenue source at a wide coverage, and this holds true particularly for developing nations (Faridy et al. 2016; George and Reddy 2015; Huang and Rios 2016). In fact, sales tax is currently the major form of consumption tax system that most countries are using (Giesecke and Tran 2012). Non-compliance to this type of tax is prevalent among developing nations (Keen and Smith 2007), and has been a critical issue for some time; thus, it is high time that its high level is mitigated (Goh et al. 2016). Furthermore, sales tax compliance has also been of concern among policy makers throughout different countries (Das-Gupta and Gang 2003), and non-compliance to it has brought about significant government losses (Nguyen 2017). In the context of Europe, the countries' level of VAT non-compliance stands at $16 \%$, but in the context of developing nations, the rate is much higher (e.g., the VAT tax non-compliance in Latin American countries is 31\% on average), and this holds the same for Jordan. Among enterprises, small and medium enterprises (SMEs) have been noted to be the drivers of the developing nations' economic growth, creating significant employment (low-large scale) opportunities through local inputs and technologies. Entrepreneurship is developed through such enterprises as they mobilize small and fragmented private savings, and owing to their key role in economies, governments have stressed the nurturing of a healthy SME sector, and have introduced several policies for their development (Hansford et al. 2003).

As for the SMEs-taxation relationship, the compliance to sales tax and the related activities has been a burden to such enterprises in comparison to compliance to other tax types (Hansford and Hasseldine 2012). There is also a great proportion of SMEs that constitutes the population of taxpayers in any country (Świstak et al. 2015), which indicates that tax payment compliance has a direct effect on the tax revenues collected by governments (Maseko 2014). However, the opposite cannot be truer, as SMEs are the most tax non-compliant entities around the globe (Alshira'h 2019), and at the same time they are the main contributors to the shadow economy of developing nations (Arachi and Santoro 2007), including Jordan. Contrary to large businesses, SMEs are operated by their owners, as a result of which they are quite responsive to personal and social factors (Świstak et al. 2015); thus, SMEs' taxation has been one of the major issues tackled by countries (developed as well as developing) since the beginning of the millennium.

Moving on to the study context, Jordan-or the Hashemite Kingdom of Jordan-is a developing Arab country in the Middle East, located off the Mediterranean sea's southeastern shores, at the junction of Asia and Africa. It is characterized by hills and an arid climate, occupying an area of 35,637 sq miles (Alshirah et al. 2021b; Haddad et al. 2017) and having a population of 1.5 million as of 1970, which increased to 9.5 million in 2015 . Thirty-five percent of the population is aged under 14 years old (Alshira'h et al. 2020a). The increasing population stems from the high birth rate and low rate of mortality in the country, with the majority of the citizens emigrating from their countries to Jordan because of political/religious reasons (e.g., from Palestine, Iraq and Syria). According to Haddad et al. (2017) the country's national income sources mostly come from foreign US and Gulf countries' aid, and from expatriates working abroad. With regards to taxes for the year 2017, Jordan gathered around $70 \%$ as governmental revenues, indicating that the country is 
largely dependent on taxes, particularly direct tax (income tax) and indirect taxes (sales tax and customs tax), with a strong inclination to the latter, which contributes approximately $68 \%$ to the tax revenue. In other words, taxes are significant for the Jordanian government (Alshira'h and Abdul-Jabbar 2020). Based on the information concerning the tax revenue size and tax non-compliance for the years spanning from 2011 and 2015, the tax revenue increased from JD3062.2 million to JD4096.8 million. Evidence over this period documented an increase in the tax non-compliance level that spiked from JD1067.4 million (2011) to JD1578.2 million (2015), a 48\% increase, while tax revenues increased by 33\% in the same time period, from JD3062.2 million to JD4096 million (Alshira'h 2018).

From the above, it is notable that the increase in non-compliance $(48 \%)$ surpassed that of the tax revenue (33\%), and based on Alshira'h (2018), the average sales tax compliance was around 71\% from 2011 to 2015, with no actual tax non-compliance estimate data being available for the year 2016. Nevertheless, the tax revenue increase constituted JD4.254 billion (Alshira'h et al. 2018), with predictions of an increase in tax non-compliance accordingly. Added to this, tax non-compliance cases relating to sales tax exceeded those for income tax non-compliance (Nsour 2014), where every JD3 collected as sales tax equated to over JD1 lost to non-compliance of the same (Alasfour 2019). Ofthe non-compliant enterprises in Jordan, $87 \%$ were small enterprises and 35\% were medium ones, which all evaded sales tax payment (Alshira'h et al. 2018). This indicates the seriousness of tax non-compliance in Jordan, with millions in tax revenues uncollected because of sales tax fraud. Consequently, the Jordanian government has had to borrow from domestic or foreign sources to make up for the tax revenue shortfall (Alkhdour 2011). In this regard, tax compliance among SMEs in Jordan could mitigate the government budget deficit, which increasingly became worse from 2010 to 2016 (from JD1.447 billion to JD1.720 billion) (Alshirah et al. 2021a; Alshira'h et al. 2018).

\section{Literature Review}

Tax compliance is an issue that has a broad reach, and in effect, researchers have defined it based on their studies' natures and objectives. To begin with, Allingham and Sandmo (1972) referred to tax compliance as the decision to declare actual income to the authorities in charge under uncertain conditions. Stated differently, taxpayers may decide whether or not to declare an accurate amount of their tax liability, depending on the probability of being found out, and on the rate of the penalty (p. 324). The empirical findings did not, however, support this model, and it is extensively known that taxpayers' compliance behavior is related with certain factors (social and psychological), which affects their innate beliefs and their attitudes, determining their behavior towards compliance (Devos 2013). Thus, Roth et al. (1989) adopted a social and psychological approach, and defined tax compliance as the accurate reporting of tax liability (p. 20), while Kirchler (2007) defined it as the willingness of the taxpayers to pay taxes (p. 21). According to Jayawardane (2015), tax compliance behavior can be deeply understood by examining the socio-psychological drivers in terms of individual, social and government factors. In their review of 18 tax compliance studies dated from 1985 to 2012, Marandu et al. (2015) reached the conclusion that the TPB is the most suitable tax framework to examine the tax compliance determinants when it comes to intention and behavior via behavioral elements (attitude towards behavior, subjective norms and perceived behavioral control). Hence, the present study used the TPB to develop the conceptual framework with five main variables, which were attitude, subjective norms, perceived behavioral control, patriotism, and the intention to comply to sales tax. These variables were reviewed in the relevant literature, after which the study hypotheses were formulated.

\subsection{Theoretical Framework-Intentions to Engage in Sales Tax Compliance}

According to the Theory of Reasoned Action (TRA), an individual's behavior is directed through the behavioral intentions of the individual - a fact that was pioneered by (Fishbein and Ajzen 1975b) in their study, which examined intention among individuals. 
However, critiques like Gentry and Calantone (2002) indicated the broad and general nature of the theory in its explanation of the relationship between attitudes, subjective norms, behavioral intention and actual behavior. In terms of taxes, general beliefs are affected by the individual's attitudes and subjective norms (Hanno and Violette 1996; Benk et al. 2011). More importantly, Ajzen (1991) proposed the Theory of Planned Behavior (TPB) as an extension of the Theory of Reasoned Action (TRA), which argues that attitudes, subjective norms and perceived behavioral control form the major determinants of the intentions of individuals to engage in a specific behavior, and eventually it affects the behavioral performance (Fishbein and Ajzen 1974). In fact, the TPB has become one of the most extensively utilized socio-psychological models that behavioral researchers have employed to shed light on and predict behavior (Armitage and Conner 2001). Its framework has been made used of by authors hailing from various disciplines to explain behavioral intentions' antecedents and the ultimate behavior. The TPB can be traced back to the Expected Utility theory, which proposed several explanatory variables that (Fishbein et al. 1980) were stated to explain any behavior of a human being. If this holds true, then behaviors are easily predictable, and the TPB could potentially assist the tax authority in their prediction and support of taxpayer behavior. The theory has been extensive applied in different disciplines, including health, psychology, leisure choice and even IT (Ajzen 1987; Ajzen and Driver 1992), but surprisingly, the theory's usage in the examination oftax compliance has yet to gain traction.

According to Ajzen's (1991) arguments, the most suitable model to provide a deeper insight into taxpayer behavior is the TPB, as it has generally been used to examine community behavior in other behavioral types as well, including traffic control (Elliott et al. 2005; Letirand and Delhomme 2005) and health (Armitage et al. 1999). However, tax payment studies have not been availing of the model's potential (Langham et al. 2012). Therefore, this study develops and brings forward a new compliance model based on the TPB to clarify the tax compliance decision-making complexity, and to develop compliance strategies for the broader population (Langham et al. 2012). In some studies, the authors extended the TPB through the addition of predictors, e.g., spirituality variables (Widuri et al. 2019). Others like Yusof and Lai (2014) related the TPB with the TRA and Fraud Diamond Theory, while Bobek and Hatfield (2003) extended the TPB by adding ethical variables, and Damayanti (2012) added cultural variables. Hence, in the present study, the TPB was extended through the addition of patriotism. According to Ajzen (1991), the TPB model can be extended through the addition of predictors in addition to attitude, subjective norms and perceived behavioral control.

\subsection{Attitude towards the Behavior (Sales Tax Compliance)}

The attitude towards tax compliance does not have a clear definition; as a result of this, it is considered to be an ambiguous construct (Eriksen and Fallan 1996). This was agreed upon by Kirchler (2007), who revealed that the tax compliance attitude is rife with complexity, representing the social construct of taxes that affects the tax compliance behavior. In this regard, attitudes refer to the evaluation of the favorableness or otherwise of an object (Fishbein et al. 1980). Based on the empirical evidence, attitude influences intention, and although extensive evidence has been provided to validate the TPB, there are only a few studies dedicated to sales tax compliance that used the model. The literature provides an instance of tax attitudes, including perceived fairness (Hite and Roberts 1992), the degree of moral reasoning that the taxpayers possess (Chan et al. 2000), increased tax knowledge (Roberts 1994), financial gain possibilities (Baldry 1987) and perceived trust in the government (Torgler 2005). In a related study, Bobek (1997) reported that the positive attitude of tax payers towards tax payment ensures a higher intention towards such a payment, whereas in Witte and Woodbury's (1985) study, the authors showed the key role of attitude in affecting intention towards tax compliance. This was supported by Bobek and Hatfield (2003), who found a significant influence of the attitude towards compliance towards tax payment. 
Added to the above, a positive attitude non-compliance behavior towards tax was established by Kirchler et al. (2008) and Trivedi et al. (2005). In fact, the evidence along this line shows that the attitude towards tax is the primary determinant of compliance or otherwise regarding tax among individuals (Jackson and Milliron 1986). Despite the fact that the attitude of taxpayers towards tax evasion is something unlawful, this does not ensure that they would adhere to the tax regulations (Onu 2016). This premise has been supported by Kuria et al.'s (2017) research on taxpayer compliance behavior in the Kenyan context, which showed the influence of the perception of government accountability for public funds management. In other words, taxpayers who perceive that tax noncompliance is unfavorable are not as likely to engage in tax non-compliance, and those who hold favorable attitudes towards tax non-compliance are more likely to engage in the same (Alleyne and Harris 2017). In this study, attitude sheds light on the confidence of the taxpayer that the tax obligation will furnish them some advantages; thus, the study proposes that:

Hypothesis 1 (H1). The attitude towards tax compliance positively relates to intentions to engage in sales tax compliance among Jordanian SMEs.

\subsection{Subjective Norms}

Another significant determinant of the tax compliance behavior of individuals is societal norms, and in Allingham and Sandmo's (1972) synthesis of prior studies, updated later by Richardson and Sawyer (2001), peer influence (subjective norms) is considered as a factor of tax compliance. In the same way, Fischer et al. (1992) highlighted the importance of subjective norms in the Fischer Model in terms of the way it explains the taxpayers' tax compliance behavior. Ajzen (1991) defined subjective norms as the global social pressure from the individuals close to the person (family and friends), who could affect the ethical decision-making of the person, with what is considered to be ethical being inconsistent universally. Stated clearly, an individual would behave a certain way if he/she is convinced that individuals close to him/her believe that he should behave in such a way (Bidin et al. 2009). Kirchler (2007) supported this argument in light of the tax compliance behavior of taxpayers, in that the group that the individual is associated with influences his behavior. In other words, if the taxpayer is convinced that other individuals are evading their taxes or cheating with them, not adhering to the regulations, then he will also be inclined towards the same (Alm 2012; Bergman 2002; Sandmo 2005). Broadly speaking, when non-compliance is deemed to be more socially acceptable, it would lead to a lower subjective probability of being detected (Alm 2012), and subjective norms in this case refer to the referent others according to (Ajzen 1991).

In prior studies, the perceived subjective norms-tax evasion relationship was supported by several authors (Bobek and Hatfield 2003; Cullis and Lewis 1997; Richardson 2006; Tsakumis et al. 2007). More specifically, Kirchler et al. (2008) contended that the belief in the extensive non-compliance among the taxpayers and its approval of their referent groups could lead to non-compliance, while Scholz (1994) indicated that others' opinion is the top driver of the change in the commitment of the respondents towards tax compliance. In a related study, a positive and significant effect was established by Bobek and Hatfield (2003) of subjective norms on tax compliance, and this was a similar to a finding reported by Trivedi et al. (2005). Bobek et al. (2013) revealed that subjective norms had a positive influence on the intention towards tax refund application for overpaid tax, and Saad (2011) supported the importance of the construct in the individual taxpayer's compliance behavior in overstating the business income scenario, as well as understating other income scenarios. In other words, taxpayers who are convinced that their referent others approve of their non-compliance to paying taxes, have a greater likelihood to engage in such behavior, while on the other hand, if the significant others frown upon tax evasion behavior, then they are not as likely to engage in non-compliance behavior. The subjective norm in the present study is referred to as the belief of the taxpayer concerning the power of influencing 
individuals and other factors in the environment towards compliance intentions; as such, this study proposes that:

Hypothesis 2 (H2). Subjective norms positively relate to intentions to engage in sales tax compliance among Jordanian SMEs.

\subsection{Perceived Behavioral Control}

The TRA was extended to the TPB (Fishbein and Ajzen 1975a) by including perceived behavioral control in order that the behaviors that are not volitional can be explainedwith PBC being the perceived ease/difficulty in performing a specific behavior (Ajzen 1991; Ajzen and Madden 1986; Beck and Ajzen 1991). In relation to this, there is direct influence of perceived behavioral control on actual behavior, via intentions. PBC has notably undergone extensive testing in terms of tax compliance behavior as an independent variable and in a full compliance model. This needs to be clarified because studies mainly refrained from adopting the TPB to shed light on tax compliance behavior according to Saad (2011). The prior studies include e.g., Ajzen (1991), Beck and Ajzen (1991), and Bobek and Hatfield (2003). The basis determined for PBC is the belief of the individual concerning the presence of resources and avenues, along with the barriers towards specific behavioral engagement (Alleyne and Harris 2017). It is noteworthy that PBC has yet to be examined by tax compliance studies, with prior studies reporting unfavorable findings on the influence of the variable on tax compliance (Hamid 2014). According to Ajzen (1991), higher levels of perceived behavioral control have a likelihood to lead to greater intentions toward behavioral performance.

Based on some of the limited studies dedicated to the PBC's role in tax compliance behavior (Bobek 1997; Trivedi et al. 2005), there is not a significant relationship between the two variables, although Bobek (1997) found that PBC interacted with subjective norms to have a significant influence on compliance intention. In a more recent study, Smart (2012) found an insignificant influence of PBC on the compliance intention towards tax law for the study sample. Based on Bobek and Hatfield (2003), PBC is not the level of ease/difficulty to evade or cheat when paying taxes, but it is the level of control that a taxpayer is convinced he has when carrying out specific activities of tax law compliance (e.g., income underreporting and expenses overstatement). PBC, according to Kirchler (2007) is the self-confidence that an individual has when filing a tax return in a way that is advantageous to him. In addition, the perception of being caught has a considerable effect on the compliance decisions of individuals, where those with low perceived behavior control (high difficulty/barriers) do not have an inclination towards tax evasion engagement. In the context of Malaysia and New Zealand, Saad (2012) found that the perceptions of justice among taxpayers in the tax system control their compliance behavior towards tax payment, and Alleyne and Harris (2017) revealed that PBC influences the avoidance of tax fraud among taxpayers. Specifically, taxpayer compliance behavior is controlled by perceptions of law enforcement, tax audits, the use of tax administration technology and high tax sanctions; these also help steer clear of negative outcomes in the future. PBC's influence on taxpayer compliance behavior represents efforts to relate the current taxpayer action and its outcome in the future. In this regard, individuals possessing high levels of PBC have a greater likelihood to engage in sales tax compliance. Thus, PBC is referred to in this study as the influence of the taxpayer and the tax system to enhance intentions towards tax compliance; as such, this study proposes that:

Hypothesis 3 (H3). The perceived behavioral control level of Jordanian SME owners-managers positively relates to their intention towards sales tax compliance engagement. 


\subsection{Patriotism}

In the realm of taxpayer compliance behavior prediction, patriotism-which implies love for one's country-is a relevant factor (Callan et al. 2006). Taxpayers' patriotism has the potential to boost higher tax payment in the country, and to prohibit the taxpayers' shift to other countries in response to the increasing rate of tax. Such a reduction in the tax base flexibility allows the demand for a higher tax level in countries (Qari et al. 2012). Hence, the patriotism of taxpayers and their wish for their country to develop are reflected in their performance of tax payment (Kahne and Middaugh 2006). Patriotic feelings play a key role in every life aspect, including tax compliance (Qari et al. 2012); as such, social identity theory should be used to examine patriotism and its effects on tax compliance (Tajfel 1974). In this study, patriotism is referred to as the affective attachment feelings and positive identification of managers of SMEs towards paying sales tax, rather than taking part in fraud to hide or evade the sales tax revenue required to be paid for the country's development. With regards to the effect of patriotic obligations on democracy, it especially stresses the difference between constructive and blind patriotism, as explained in Kahne et al. (2006). The authors revealed that constructive patriotism is the applauding of some government work and the exposing and criticizing of others for positive alteration and consistency. Contrastingly, blind patriotism refers to the promotion of unquestioning approval towards the state, refraining from analysis and criticism, basically cementing all-sizing loyalty and symbolic activities. Blind patriots are thus those that are nationalists, supporting the notability of their nations and hegemony over other nations.

Moreover, nationalism is different from patriotism (Druckman 1994), with patriotism being the love of a state that is not related to a certain conflict schema; despite such a relation, it composes a more positive cooperation with other nations. Patriotism is not related to hostility towards other nations or outsiders within the nation. Comparably, nationalism refers to a form of racism towards other ethnicities, in that positive sensation is placed on nationality and hostility is placed on other nations or nation groups. In other words, nationalism is linked to passive feelings towards foreign states, outsiders inside one's nation, and the inclination towards hegemony with other countries. Similarly, patriotism was referred to by Ben-Porath (2012) as a morally preferable form of attachment to a political community, which is inclusive and respectful of the fundamental rights of individuals and groups, whereas nationalism refers to intolerance, exclusionism or violence. In another related study, the difference between the two was drawn by Costa (2018) in light of their objectives-the majority of countries constitute more than one nation within their borders, with some extending to more than a single state; as a result of this, patriotic and nationalist targets do not coincide. Moreover, the most appropriate way to differentiate between the two is through their focus on loyalty objectives, with patriotism involving loyalty to one's nation, and nationalism involving loyalty to a people. Added to this, the objective behind patriotism is primarily an institutionalized political community like a country, including its fellow citizens, sharing legal and political institutions among themselves, while in nationalism, the objective is a group of people sharing a common identity.

Patriotism played a key role in encouraging taxpayers to promote the stability of the government during the Second World War (Konrad and Qari 2012). The focus on patriotism's effects on tax obligation was compounded during war times and conflicts, while during the time of peace, patriotism is not as high. In the past ten years, a debate has been rampant concerning US taxation and patriotism, and this held particularly true in the 2008 presidential election campaign, where Vice Presidential Candidate Joe Biden claimed that Americans pay their taxes as a patriotic obligation, and in the same way, Presidential Candidate Senator John Kerry claimed that taxes are patriotism-dependent (MacGregor and Wilkinson 2012). According to other studies, the influence of patriotism leads to economic revival and national development (Ochulor 2011), and patriotic individuals are inclined towards paying for public transportation in their country (Doerrenberg 2015). Furthermore, the internal motivation of tax obligation behavior stems from intrinsic personal norms 
like patriotism (Kornhauser 2007), although taxpayers should give patriotic value towards paying their taxes (Wynter 2014).

In the context of MacGregor and Wilkinson's (2012) study, taxpayers' patriotism has a positive relationship with increased tax compliance, with non-compliance considered to be unpatriotic by the patriotic taxpayers. Such findings are aligned with those found by Konrad and Qari (2012). Nevertheless, other studies like Gangl et al. (2016) reported no significant direct effect of patriotism on tax compliance, although it has an indirect significant effect through trust on tax authority and voluntary cooperation. On the basis of the above literature, only a few empirical studies have been dedicated to the relationship between patriotism and tax compliance, with the majority of them ignoring OECD countries. In sum, patriotism is a significant determinant of tax compliance behavior, although it has not been consistently supported, as studies concerning patriotism and income tax compliance have been few and far between. To the best of the researchers' knowledge, no study has been carried out on the patriotism-sales tax compliance relationship, with prior studies on the patriotism-tax compliance relationship being limited to the individual level, leaving SMEs' sales tax compliance behind. Hence, studies are suggested to add to the evidence of the relationship between patriotism and sales tax compliance among Middle Eastern SMEs. On the basis of the above discussion of the literature, this study proposes that:

Hypothesis 4 (H4). Patriotism positively relates to intentions towards engaging in sales tax compliance among Jordanian SMEs.

Based on the above reviewed literature, the present study brings forward the following conceptual framework (Figure 1).

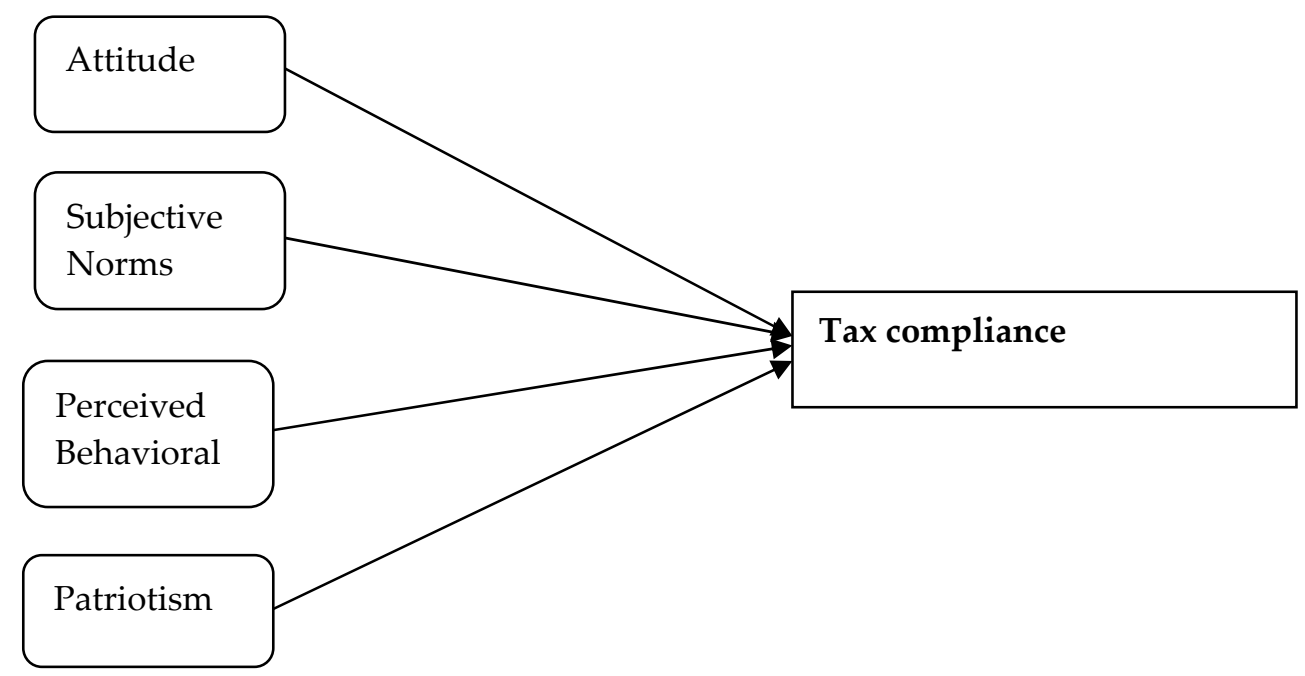

Figure 1. Research framework for tax compliance.

\section{Methodology}

The study adopted a quantitative approach to test the formulated hypotheses. The quantitative approach provided confirms the conceptual model with the constituting variables statistically. For this approach, a questionnaire was developed for data collection to gather data about the attitudes of the respondents towards tax compliance behavior, PBC, subjective norms, patriotism, and intentions towards sales tax compliance engagement in the SMEs of Jordan. The effects of the attitudes towards the behavior, subjective norms, perceived behavioral control, and patriotism on the intentions towards engagement in sales tax compliance were measured in this context. The sample comprises SMEs listed in Jordan (Lutfi et al. 2017), with small businesses being enterprises that have 10-49 full-time employees, and medium ones having 50-249 full-time employees. The study's unit of 
analysis is the organization that owner-managers represent, with these being individuals who have key roles in the tax decisions among SMEs (Kamleitner et al. 2012). They generally hold the suitable information and knowledge concerning the financial affairs of the enterprises (Lignier and Evans 2012). Among SMEs in Jordan, the owner is generally the manager, and they have the likelihood to take part in decisions on compliance issues.

Prior to the actual data collection, the participants were informed of the study's nature and purpose, and their consent was taken prior to the data collection. They were also informed that their participation in the survey was voluntary, and so they could drop out at any time-all of these were included in the questionnaire instructions. The respondents were ensured anonymity by our refraining from obtaining names, addresses and contact information. The questionnaire items were developed to avoid confusion and ambiguity, and the anticipation of any negative outcome was ensured, whether physical or psychological. These safeguards were all practiced so as not to breach any ethical issues which could arise owing to the sensitivity and incriminating nature of the research.

Therefore, as mentioned, a self-administered questionnaire was used for the data collection, and a comprehensive updated list of the SMEs from the manufacturing sector in Jordan was used as a sampling frame. Specifically, the list was obtained from the Jordan Chamber of Industry (JCI), containing manufacturing SMEs' names and details, by officially applying for it. There are 17,749 manufacturing SMEs in Jordan. Through the list, details of the SMEs including their name, phone number and email were included. The JCI mandates any business in the country to register in order to obtain a work license. As for the size of the sample based on the population size, it was calculated to be 377 out of 17,749 firms, based on Krejcie and Morgan's (1970) calculation. However, in order to obtain a high rate of response, which is a common issue when it comes to Jordanian SMEs (Lutfi 2017, 2020; Lutfi et al. 2017), the sample size was increased based on the suggestion of Israel (1992). This trend is based on prior literature that showed the non-response rate varying from 70 to $75 \%$ in Jordanian businesses (Lutf and Mohamad 2016).

Therefore, the present study increased the sample size by $75 \%$, in that included 660 SMEs to collect data from. The sample selection procedure adopted was the probability sampling method because of its lower bias and ability to produce generalizable findings (Sekaran and Bougie 2003; Zikmund et al. 2013). Accordingly, a systematic random sampling method was used to choose 660 respondents from the JCI list, with the sampling interval being the population/sample size, $17,749 / 660=27$. The researcher made use of the number 27, in the sense that the sampling elements chosen were $27,54,81$ and so on, to the last selected sample (660). A total of 398 (60.3\%) questionnaires were returned out of the total 660, but 13 questionnaires were dropped because they contained issues, leaving $385(58 \%)$ questionnaires useable for the analysis.

The measurement items used to gauge the five latent variables were adopted from the past literature as shown in Table 1, and a 5-point Likert scale was used, ranging from strongly disagree (1) to strongly agree (5). To begin with, the measurement items of attitude were seven in number, and they were adopted from Beck and Ajzen (1991) and Bobek and Hatfield (2003); the subjective norm items were four in number, and were adopted from the same authors. Moving on to PBC, its measurement items numbered six statements, and they were adopted from MacGregor and Wilkinson (2012). The patriotism items were six in number, and were adopted from MacGregor and Wilkinson (2012). Lastly, the behavioral intention of sales tax compliance items were three in number, and were adopted from Beck and Ajzen (1991). The five latent variable items were tweaked to suit the study context, which was tax compliance among SMEs. Operational definitions of the five latent variables as shown in following Table 2: 
Table 1. Measurement of the variables.

\begin{tabular}{|c|c|c|}
\hline Variable & Items & Source \\
\hline 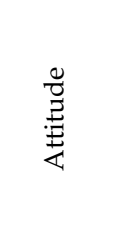 & $\begin{array}{l}\text { 1. Sales tax compliance is good. } \\
\text { 2. Engaging in Sales tax compliance wise. } \\
\text { 3. Sales tax compliance can be useful. } \\
\text { 4. I find the concept of sales tax compliance attractive. } \\
\text { 5. I think I would pay more sales taxes if I engaged in sales tax compliance. } \\
\text { 6. I would be pleased if I paid more sales taxes because I engage in sales tax compliance. } \\
\text { 7. Cheating on sales taxes is unpleasant. }\end{array}$ & $\begin{array}{c}\text { (Beck and Ajzen 1991; } \\
\text { Bobek and Hatfield 2003) }\end{array}$ \\
\hline 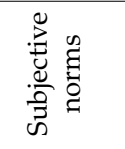 & $\begin{array}{l}\text { 1. Most people I know would approve of me to pay sales taxes. } \\
\text { 2. If I comply on my sales taxes, most people who are important to me would. } \\
\text { 3. No one who is important to me thinks it is ok to cheat on sales taxes. } \\
\text { 4. Most people who are important to me will look down on me if I cheat on Sales taxes. }\end{array}$ & $\begin{array}{c}\text { (Beck and Ajzen 1991; } \\
\text { Bobek and Hatfield 2003) }\end{array}$ \\
\hline 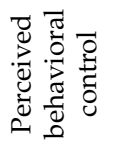 & $\begin{array}{l}\text { 1. For me to cheat on sales taxes, it is difficult. } \\
\text { 2. If I want to, I can comply on sales taxes. } \\
\text { 3. I can imagine times when I might comply on sales taxes even if I hadn't planned to. } \\
\text { 4. Even if I had a good reason, I could not bring myself to cheat on sales taxes. }\end{array}$ & (Beck and Ajzen 1991) \\
\hline 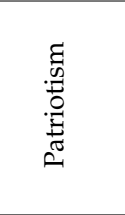 & $\begin{array}{l}\text { 1. Businesses are more patriotic when they buy goods made in Jordan thangoods made in other countries. } \\
\text { 2. A business that pays more in sales taxes is more patriotic than a business that pays less in taxes. } \\
\text { 3. A person who cheats on his/her sales taxes is not patriotic. } \\
\text { 4. A business that hides its sales revenue in a foreign country to avoid sales taxes is not patriotic. } \\
\text { 5. Businesses that cheat on sales taxes are not patriotic. } \\
\text { 6. I would be willing to increase sales tax rate if it would help my country. }\end{array}$ & $\begin{array}{l}\text { (MacGregor and } \\
\text { Wilkinson 2012) }\end{array}$ \\
\hline 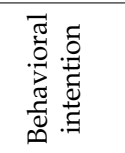 & $\begin{array}{l}\text { 1. If I had the opportunity, I wouldn't cheat on sales tax. } \\
\text { 2. I would never cheat on sales tax. } \\
\text { 3. I wouldn't cheat on sales tax in the future. }\end{array}$ & (Beck and Ajzen 1991) \\
\hline
\end{tabular}

Table 2. Operational definitions of the variables.

\begin{tabular}{cr}
\hline Latent Construct & $\begin{array}{c}\text { Operationalization } \\
\text { Attitude }\end{array}$ \\
$\begin{array}{c}\text { The positive or negative direction and the intensity of the perceived favorable or } \\
\text { unfavorable disposition of a person toward an object (Ajzen 2006) }\end{array}$ \\
$\begin{array}{c}\text { The pressure from important others which is referred to in this study as the parents } \\
\text { referents, the colleagues' referents, the employers' referents and the spouse referents to } \\
\text { perform a behavior Adapted from (Rhodes et al. 2006) }\end{array}$ \\
\hline Perceivedbehavioural control & $\begin{array}{r}\text { Perceived behavior control is an individual factor how a person controls himself to behave } \\
\text { (Ajzen 1991) }\end{array}$ \\
\hline Patriotism & Patriotism implies love of one's country (Callan 2006) \\
\hline Behavioral intention & An individual's readiness to perform a behavior or action Adapted (Ajzen 2006)
\end{tabular}

\section{Data Analysis}

Partial Least Squares-Structural Equation Modeling (PLS-SEM) analysis was adopted for this study using Smart PLS3 to test the formulated hypotheses and conduct an analysis of the research model. PLS-SEM is basically a statistical instrument that has been garnering support from researchers using it for empirical data analysis to test different relationships in a simultaneous manner (Ringle et al. 2012). It is suitable to use for the investigation of complex models with a significant number of items, variables and relationships, as described by Chin (2010), and it is capable of investigating even small samples (Hair et al. 2014). PLS-SEM is not concerned with the normality of data (Sarstedt et al. 2014); thus, it can be used when other methods are not appropriate to be used. It consists of a two-stage procedure (Hair et al. 2019), which involves the measurement model (outer model) and the structural model (inner model), with the former being used to assess the reliability and validity of the constructs and indicators, and the latter being used to evaluate the hypothesized relationships in terms of their significance. 


\subsection{Assessment of the Measurement Model}

This study evaluated the measurement model in terms of its convergent validity and discriminant validity. More specifically, convergent validity refers to the extent to which the variables' indicators represent and measure the variables accurately, and to which they appropriately correlate with other measures of the same variables (Hair et al. 2014). This type of validity is assessed by the evaluation of the indicators' loadings, by Cronbach's alpha, by Composite Reliability (CR), and by the Average Variance Extracted (AVE). Table 3 tabulates the indicator loadings, Cronbach's Alpha values, and Composite Reliability values, and it is evident that they all exceed the threshold values of 0.40 and 0.70 (Hair et al. 2019). On the basis of the results, the convergent validity was confirmed.

Table 3. Convergent validity assessment.

\begin{tabular}{|c|c|c|c|c|c|}
\hline Latent Construct & Items & Loading & CA & CR & AVE \\
\hline \multirow{7}{*}{ Attitude (AT) } & AT1 & 0.635 & \multirow{7}{*}{0.836} & \multirow{7}{*}{0.878} & \multirow{7}{*}{0.504} \\
\hline & AT2 & 0.681 & & & \\
\hline & AT3 & 0.735 & & & \\
\hline & AT4 & 0.744 & & & \\
\hline & AT5 & 0.732 & & & \\
\hline & AT6 & 0.746 & & & \\
\hline & AT7 & 0.686 & & & \\
\hline \multirow{4}{*}{ Subjective Norms (SN) } & SN1 & 0.813 & \multirow{4}{*}{0.808} & \multirow{4}{*}{0.872} & \multirow{4}{*}{0.629} \\
\hline & SN2 & 0.822 & & & \\
\hline & SN3 & 0.746 & & & \\
\hline & SN4 & 0.790 & & & \\
\hline \multirow{4}{*}{ Perceived Behavioral (PB) } & PB1 & 0.790 & \multirow{4}{*}{0.722} & \multirow{4}{*}{0.825} & \multirow{4}{*}{0.544} \\
\hline & PB2 & 0.667 & & & \\
\hline & PB3 & 0.823 & & & \\
\hline & PB4 & 0.656 & & & \\
\hline \multirow{6}{*}{ Patriotism (PA) } & PA1 & 0.774 & \multirow{6}{*}{0.820} & \multirow{6}{*}{0.871} & \multirow{6}{*}{0.531} \\
\hline & PA2 & 0.807 & & & \\
\hline & PA3 & 0.677 & & & \\
\hline & PA4 & 0.774 & & & \\
\hline & PA5 & 0.741 & & & \\
\hline & PA6 & 0.585 & & & \\
\hline \multirow{3}{*}{ Behavioral Intention (BI) } & BI1 & 0.866 & \multirow{3}{*}{0.856} & \multirow{3}{*}{0.913} & \multirow{3}{*}{0.777} \\
\hline & $\mathrm{BI} 2$ & 0.850 & & & \\
\hline & $\mathrm{BI} 3$ & 0.926 & & & \\
\hline
\end{tabular}

Following the confirmation of the convergent validity, the discriminant validity was examined using Fornell-Larcker's criterion, as recommended by Hair et al. (2014). The discriminant validity of the latent constructs was confirmed through the comparison of the AVE square roots and the variables' correlation coefficients. Table 4 shows that the AVE square roots exceeded the diagonal values in the respective rows and columns, which is indicative of the presence of discriminant validity among the variables. It can be stated that the measurement model achieved the requirements in light of the validity and reliability (reliability, and convergent and discriminant validity) at the level of the indicators and variables. 
Table 4. Discriminant validity assessment.

\begin{tabular}{cccccc}
\hline Variables & AT & SN & PB & PA & BI \\
\hline AT & $\mathbf{0 . 8 4 0}$ & & & & \\
SN & 0.010 & $\mathbf{0 . 7 3 0}$ & & & \\
PB & 0.011 & 0.168 & $\mathbf{0 . 7 8 6}$ & & \\
PA & -0.092 & 0.286 & 0.167 & $\mathbf{0 . 8 3 8}$ & \\
BI & 0.062 & 0.186 & -0.078 & 0.156 & $\mathbf{0 . 7 9 4}$ \\
\hline
\end{tabular}

The measurement model was evaluated using PLS-SEM, in that the $R^{2}$ value and the amount of variance interpreted by the exogenous variable were obtained. This value is a reflection of the variance value of the dependent construct that is interpretable by one or more independent constructs (Hair et al. 2020). The three constructs showed an $R^{2}$ value of 0.397 , which means that attitude, subjective norms and perceived behavioral control, and patriotism explained $39.7 \%$ of the variance in the intention to engage in sales tax compliance.

\subsection{Structural Model Assessment}

The structural model testing aims to examine the effect of the exogenous variable on the endogenous one. Accordingly, the structural model has four primary evaluation criteria, namely the variance explained $\left(R^{2}\right)$, effect size $\left(f^{2}\right)$, predictive relevance $\left(Q^{2}\right)$, path coefficient ( $\beta$ ), and hypotheses' testing results (Chin 2010; Hair et al. 2017; Henseler et al. 2009). The path coefficients' significance was examined using the bootstrapping method function using 5000 re-samples. Table 5 shows that the attitudes towards tax compliance were significantly related to intentions to engage in sales tax compliance $(\beta=0.150, t=2.732$, $p<0.05)$, indicating that the owners-managers of SMEs that had positive attitudes towards tax compliance had a higher likelihood to engage in sales tax compliance. In addition, subjective norms were significantly related to intentions to engage in sales tax compliance ( $\beta=0.187 ; t=6.125 ; p<0.01)$, indicating that the owners and managers of SMEs that had high subjective norms had a higher likelihood to engage in sales tax compliance. Along a similar line of significant findings, perceived behavioral control was significantly related to intentions to engage in sales tax compliance $(\beta=0.163, t=2.053, p<0.05)$, revealing that SMEs' owner-managers with high perceived behavioral control were more inclined towards engaging in sales tax compliance. Finally, patriotism was found to be significantly related to intentions to engage in sales tax compliance $(\beta=0.185, \mathrm{t}=2.624, p<0.05)$, indicating that the owners and managers of SMEs who were patriotic had a higher likelihood to engage in sales tax compliance. In sum, the results fully supported hypotheses H1, H2, H3 and H4.

Table 5. Result of the hypothesis testing.

\begin{tabular}{|c|c|c|c|c|c|c|c|}
\hline $\begin{array}{c}\text { Hypothesis } \\
\text { No. }\end{array}$ & Relationship & $\begin{array}{c}\text { Path } \\
\text { Coefficient }\end{array}$ & T-Value & $p$-Value & Decision & $R^{2}$ & $f^{2}$ \\
\hline $\mathrm{H} 1$ & AT $->$ STC & 0.150 & 2.732 & $0.006^{* *}$ & Supported & 0.397 & 0.130 \\
\hline $\mathrm{H} 2$ & $\mathrm{SN} \rightarrow \mathrm{STC}$ & 0.079 & 0.121 & $0.000 * *$ & Supported & & 0.132 \\
\hline $\mathrm{H} 3$ & PB -> STC & 0.163 & 2.053 & $0.040 *$ & Supported & & 0.123 \\
\hline $\mathrm{H} 4$ & PA $->$ STC & 0.185 & 2.624 & $0.009 * *$ & Supported & & 0.121 \\
\hline
\end{tabular}

Note: ${ }^{*} p<0.05,{ }^{* *} p<0.01$ (one-tailed).

\subsection{Predictive Relevance of the Model}

In this study, the predictive relevance of the model was tested using the Stone-Geisser test, through the blindfolding approach (Geisser 1974; Stone 1974). The blindfolding technique was applied to determine the predictive relevance of the model, as suggested by Sattler et al. (2010), because they stated that the "blindfolding procedure is only applied to endogenous latent variable that have reflective measurement model operationalization". The premise behind reflective measurement is that a latent construct produces a variation on 
observable items. The entire endogenous latent construct is reflective; thus, a blindfolding technique was employed in its analysis, where a cross-validated redundancy measure $\left(Q^{2}\right)$ was employed to determine the predictive relevance of the model, as suggested by the prior literature (Chin 2010; Geisser 1974; Hair et al. 2013; Ringle et al. 2012; Stone 1974). According to Chin (1998) and Hair et al. (2014), the cross-validated redundancy measure $\left(\mathrm{Q}^{2}\right)$ determines the way in which the model predicts the data of omitted cases, while Henseler et al. (2009) explained that a $Q^{2}$ statistic exceeding zero represents predictive relevance. Added to this, a model with a higher positive $Q^{2}$ value has higher predictive relevance. Table 6 presents the cross-validated redundancy $Q^{2}$ value for this study. Based on Cohen's (1988) suggestion, $f^{2}$ values of 0.02 represent small impacts, values of 0.15 represent medium impacts, and values of 0.35 represent large impacts in the structural model.

Table 6. Construct cross-validated redundancy $\left(\mathrm{Q}^{2}\right)$.

\begin{tabular}{cccc}
\hline Endogenous Latent Variables & SSO & SSE & 1-SSE/SSO \\
\hline Sales Tax Compliance & 1484.000 & 1343.060 & 0.091 \\
\hline
\end{tabular}

Based on the above table (Table 6), the $\mathrm{Q}^{2}$ value for the endogenous latent construct exceeds zero, confirming the predictive relevance of the model according to Chin (1998) and Henseler et al. (2009).

\section{Conclusions}

The paper primarily aimed to investigate the influencing factors of SMEs' ownermanagers' engagement in sales tax compliance in the Jordanian context. On the basis of the obtained findings, a positive attitude towards sales tax compliance lead to easy performance, and this held true for patriotism in boosting higher intentions towards sales tax compliance engagement. All of the hypotheses ( $\mathrm{H1}, \mathrm{H} 2, \mathrm{H} 3$ and $\mathrm{H} 4)$ were supported by the study using Ajzen (1991) and Beck and Ajzen's (1991) models.

More specifically, significant support was obtained for PBC as a significant predictor and driver of sales tax compliance, as aligned with the results reported by prior studies in the literature (Carnes and Englebrecht 1995; Robben et al. 1990). PBC reflects the opportunities and barriers, and as such, it can be stated that the tax authority can be enhanced to make tax compliance easier, and to deter non-compliance. Accordingly, governments can establish penalties to enhance the former, while balancing this against potential abuse by the tax authority (corruption or harsh penalization) for honest mistakes or oversight by the taxpayers (Slemrod 2007).

Another significant predictor of sales tax compliance is attitude, and SMEs are generally reported as having high tax non-compliance; as such, in effect, changing attitudes could be promoted through effective communication (seminars, media use, etc.) in order to make the public aware of the requirement of tax payment. Furthermore, because of the adverse attitude towards the tax authorities by the SMEs, tax staff should be trained to inform and raise awareness among customers through increased customer service levels, increased courtesy, assistance and service convenience. Such a service-centered approach is expected to help the taxpayers to be viewed as a potential client, rather than a potential criminal (Bird and Zolt 2008).

In the context of developing nations, the spirit of trust in enabling tax self-declaration has to be focused on by the tax policymakers in order to boost citizens' tax payment, as this will instill confidence and credibility in the delivery of tax returns from the collected taxes (Torgler 2005). With regard to patriotism, it was found to have a positive relationship with the intention to engage in sales tax compliance among SMEs in Jordan, and this result is consistent with the prior literature (Woodward and Tan 2015). This finding shows that tax compliance is enhanced with high levels of patriotic feelings for one's country. At the individual level, income tax compliance was also found to have a significant relationship to compliance with tax payment (Gangl et al. 2016; Konrad and Qari 2012; MacGregor 
and Wilkinson 2012). The study analysis results reaffirmed the outcome of prior studies concerning the influence of patriotism on the engagement in sales tax compliance. The current study contributes to the extension of the TPB by the inclusion of patriotism as a determinant of sales tax compliance in the context of SMEs in Jordan.

\section{Implications and Limitations}

The current study focused on the examination of the determinants of sales tax compliance among SMEs in Jordan using an extended TPB framework; in so doing, it minimizes the gaps in the literature on tax compliance. Prior studies were confined in their focus on the patriotism law on income tax, with the sales tax lagging behind; this study, based on the authors' best knowledge, is among the first studies to examine patriotism's effect on the intention towards sales tax compliance among SMEs. In other words, this study offers a new dimension to the literature on tax compliance.

Prior studies that examined the influencing factors of the intention towards tax compliance combined various relevant TPB factors but no single model has been successful in accounting for such compliance, and no study has extended the TPB by including patriotism as an independent variable. This study considered patriotism as a potential key determinant that affects the sales tax compliance intention in Jordanian SMEs. Suffice it to say, tax compliance behavior affects the economy and the whole equitable and efficient tax system, changing the economic resource allocation system. This is why economists are constantly focused on tax compliance behavior, owing to its significant influence on the whole economy of the country.

With regard to the implications to practice, this study provides tax authorities, governments and policymakers in Jordan with relevant tax compliance information. To begin with, patriotism and related behaviors can support the sales tax payment environment of SMEs. Furthermore, relevant tax actors should promote high-quality public governance through suitable education, fundamental infrastructure development, safety of life, property, peaceful law and order, new job creation, private- and public-sector opportunities, effective and efficient government, good business surroundings with a free-market economy, the decrease of the digital divide, the increase of positive societal effects, liberty in speech and work, non-interference from the government, and citizens' readiness to pay taxes for quality services.

Similarly to other studies, the present one has several limitations. First, the study focused on sales tax compliance intention in Jordan, a Middle Eastern country, and while the study framework can be used by researchers, caution should be taken as to the findings' generalization, owing to the limited geographical area. In this regard, future authors can use the study model and test it in other Arab countries.

Another limitation is the use of a quantitative approach-future authors can combine quantitative and qualitative approaches (questionnaires, case studies and interviews) to generate deep insights into the topic, and to provide the accurate validation of the findings. Such a combined approach or mixed-approach could cover various perspectives and tackle the limitations that arise from one single approach. Lastly, this study largely depended on a dataset obtained from a self-report survey, which could have led to the occurrence of biased and dishonest data. In order to mitigate such an occurrence, indirect questions with anonymity support could be adopted.

Author Contributions: T.B.-K.: conceptualization, original draft preparation, writing; A.F.A.: validation, resources; data curation, project administration; M.H.A.: theoretical analysis review, methodology and edit. All authors have read and agreed on the published version of the manuscript.

Funding: This research received no external funding.

Conflicts of Interest: The authors declare no conflict of interest. 


\section{References}

Abdixhiku, Lumir, Geoffrey Thomas Pugh, and Iraj Hashi. 2018. Business tax evasion in transition economies: A cross-country panel investigation. European Journal of Comparative Economics 15: 11-36.

Achek, Imen. 2015. The determinants of tax evasion: A literature review. International Journal of Law and Management 57: 486-97.

Adams, Caroline, and Paul Webley. 2001. Small business owners' attitudes on VAT compliance in the UK. Journal of Economic Psychology 22: 195-216. [CrossRef]

Ajzen, Icek. 1987. Attitudes, traits, and actions: Dispositional prediction of behavior in personality and social psychology. Advances in Experimental Social Psychology 20: 1-63.

Ajzen, Icek. 1991. The theory of planned behavior. Organizational Behavior and Human Decision Processes 50: 179-211. [CrossRef]

Ajzen, Icek. 2006. Constructing a Theory of Planned Behavior Questionnaire. Amherst: University of Massachusetts.

Ajzen, Icek, and Beverly L. Driver. 1992. Application of the theory of planned behavior to leisure choice. Journal of Leisure Research 24: 207-24. [CrossRef]

Ajzen, Icek, and Thomas J. Madden. 1986. Prediction of goal-directed behavior: Attitudes, intentions, and perceived behavioral control. Journal of Experimental Social Psychology 22: 453-74. [CrossRef]

Alasfour, Fadi. 2019. Costs of distrust: The virtuous cycle of tax compliance in Jordan. Journal of Business Ethics 155: 243-58. [CrossRef]

Alkhdour, Rajeh. 2011. Estimating the Shadow Economy in Jordan: Causes, Consequences, and Policy Implications. Ph.D. dissertation, Colorado State University, Fort Collins, CO, USA.

Alleyne, Philmore, and Terry Harris. 2017. Antecedents of taxpayers' intentions to engage in tax evasion: Evidence from Barbados. Journal of Financial Reporting and Accounting 15: 2-21. [CrossRef]

Allingham, Michael G., and Agnar Sandmo. 1972. Income tax evasion: A theoretical analysis. Journal of Public Economics 1: 323-38. [CrossRef]

Alm, James. 2012. Measuring, explaining, and controlling tax evasion: Lessons from theory, experiments, and field studies. International Tax and Public Finance 19: 54-77. [CrossRef]

Alm, James, and Asmaa El-Ganainy. 2013. Value-added taxation and consumption. International Tax and Public Finance 20: 105-28. [CrossRef]

Alm, James, Yongzheng Liu, and Kewei Zhang. 2019. Financial constraints and firm tax evasion. International Tax and Public Finance 26: 71-102. [CrossRef]

Alshir'ah, Ahmad Farhan, Hijattulah Abdul-Jabbar, and Rose Shamsiah Samsudin. 2016. Determinants of sales tax compliance in small and medium enterprises in Jordan: A call for empirical research. Small 10: 49.

Alshira'h, Ahmad Farhan. 2018. Determinants of Sales Tax Compliance among Jordanian SMEs: The Moderating Effect of Public Governance. Bukit Kayu Hitam: Universiti Utara Malaysia.

Alshira'h, Ahmad Farhan. 2019. The effect of peer influence on sales tax compliance among Jordanian SMEs. International Journal of Academic Research in Business and Social Sciences 9: 710-21.

Alshira'h, Ahmad Farhan, and Hijattulah Abdul-Jabbar. 2019a. A conceptual model of sales tax compliance among Jordanian SMEs and its implications for future research. International Journal of Economics and Finance 11: 114-14. [CrossRef]

Alshira'h, Ahmad Farhan, and Hijattulah Abdul-Jabbar. 2019b. The effect of tax fairness on sales tax compliance among Jordanian manufacturing SMEs. Academy of Accounting and Financial Studies Journal 23: 1-11.

Alshira'h, Ahmad Farhan, and Hijattulah Abdul-Jabbar. 2020. Moderating role of patriotism on sales tax compliance among Jordanian SMEs. International Journal of Islamic and Middle Eastern Finance and Management 13: 389-415. [CrossRef]

Alshira'h, Ahmad Farhan, Hijattulah Abdul-Jabbar, and Rose Shamsiah Samsudin. 2018. Sales tax compliance model for the Jordanian small and medium enterprises research. Journal of Advanced Research in Social and Behavioural Sciences 10: 115-30.

Alshira'h, Ahmad Farhan, Hijattulah Abdul-Jabbar, and Rose Shamsiah Samsudin. 2019. The effect of tax moral on sales tax compliance among Jordanian SMEs. International Journal of Academic Research in Accounting, Finance and Management Sciences 9: 30-41. [CrossRef]

Alshira'h, Ahmad Farhan, Manaf Al-Okaily, Abdalwali Lutfi, and Malek Hamed Alshirah. 2020a. Do public governance and patriotism matter? Sales tax compliance among small and medium enterprises in developing countries: Jordanian evidence. EuroMed Journal of Business 16: 431-55. [CrossRef]

Alshira'h, Ahmad Farhan, Moh Alsqour, Abdalwali Lutfi, Adi Alsyouf, and Malek Alshirah. 2020b. A Socio-Economic Model of Sales Tax Compliance. Economies 8: 88. [CrossRef]

Alshira'h, Ahmad, Ali Magablih, and Moh Alsqour. 2021. The effect of tax rate on sales tax compliance among Jordanian public shareholding corporations. Accounting 7: 883-92.

Alshirah, Malek, Abdalwali Lutfi, and Ahmad Farhan Alshira'h. 2021a. Influences of the environmental factors on the intention to adopt cloud based accounting information system among SMEs in Jordan. Accounting 7: 645-54. [CrossRef]

Alshirah, Malek Hamed, Ahmad Farhan Alshira'h, and Abdalwali Lutfi. 2021b. Political connection, family ownership and corporate risk disclosure: Empirical evidence from Jordan. Meditari Accountancy Research.

Arachi, Giampaolo, and Alessandro Santoro. 2007. Tax enforcement for SMEs: Lessons from the Italian experience. eJTR 5: 225.

Armitage, Christopher J., and Mark Conner. 2001. Efficacy of the theory of planned behaviour: A meta-analytic review. British Journal of Social Psychology 40: 471-99. [CrossRef] [PubMed] 
Armitage, Christopher J., Christopher J. Armitage, Mark Conner, Justin Loach, and David Willetts. 1999. Different perceptions of control: Applying an extended theory of planned behavior to legal and illegal drug use. Basic and Applied Social Psychology 21: 301-16. [CrossRef]

Azmi, Anna, Noor Sharoja Sapiei, Mohd Zulkhairi Mustapha, and Mazni Abdullah. 2016. SMEs' tax compliance costs and IT adoption: The case of a value-added tax. International Journal of Accounting Information Systems 23: 1-13. [CrossRef]

Baldry, Jonathan C. 1987. Income tax evasion and the tax schedule: Some experimental results. Public Finance Finances Publiques 42: 357-83.

Beck, Lisa, and Icek Ajzen. 1991. Predicting dishonest actions using the theory of planned behavior. Journal of Research in Personality 25 285-301. [CrossRef]

Benk, Serkan, Ahmet Ferda Cakmak, and Tamer Budak. 2011. An investigation of tax compliance intention: A theory of planned behavior approach. European Journal of Economics, Finance and Administrative Sciences 28: 180-88.

Ben-Porath, Sigal. 2012. Citizenship as shared fate: Education for membership in a diverse democracy. Educational Theory 62: 381-95. [CrossRef]

Bergman, Marcelo S. 2002. On Trust, Deterrence and Compliance: The Sociology of Tax Evasion in Argentina. San Diego: University of California.

Besley, Timothy, and Torsten Persson. 2014. Why do developing countries tax so little? Journal of Economic Perspectives 28: 99-120. [CrossRef]

Bidin, Zainol, Kamil Md Idris, and Faridahwati Mohd Shamsudin. 2009. Predicting compliance intention on zakah on employment income in Malaysia: An application of reasoned action theory. Jurnal Pengurusan (UKM Journal of Management) 28: 85-102.

Bird, Richard M., and Eric M. Zolt. 2008. Technology and taxation in developing countries: From hand to mouse. National Tax Journal 61: 791-821. [CrossRef]

Bobek, Donna Denise. 1997. Tax Fairness: How Do Individuals Judge Fairness and What effect Does It Have on Their Behavior. Gainesville: University of Florida.

Bobek, Donna D., and Richard C. Hatfield. 2003. An investigation of the theory of planned behavior and the role of moral obligation in tax compliance. Behavioral Research in Accounting 15: 13-38. [CrossRef]

Bobek, Donna D., Amy M. Hageman, and Charles F. Kelliher. 2013. Analyzing the role of social norms in tax compliance behavior. Journal of Business Ethics 115: 451-68. [CrossRef]

Callan, Eamonn. 2006. Love, idolatry, and patriotism. Social Theory and Practice 32: 525-46. [CrossRef]

Callan, Tim, Kieran Coleman, and John Walsh. 2006. Assessing the impact of tax/transfer policy changes on poverty: Methodological issues and some European evidence. Research in Labor Economics 25: 125-39.

Carnes, Gregory A., and Ted D. Englebrecht. 1995. An investigation of the effect of detection risk perceptions, penalty sanctions, and income visibility on tax compliance. The Journal of the American Taxation Association 17: 26.

Carsamer, Emmanuel, and Anthony Abbam. 2020. Religion and tax compliance among SMEs in Ghana. Journal of Financial Crime. [CrossRef]

Chan, Chris W., Coleen S. Troutman, and David O'Bryan. 2000. An expanded model of taxpayer compliance: Empirical evidence from the United States and Hong Kong. Journal of International Accounting, Auditing and Taxation 9: 83-103. [CrossRef]

Chan, Sok-Gee, Zulkufly Ramly, and Mohd Zaini Abd Karim. 2017. Government spending efficiency on economic growth: Roles of value-added tax. Global Economic Review 46: 162-88. [CrossRef]

Chin, Wynne W. 1998. The partial least squares approach to structural equation modeling. Modern Methods for Business Research 295: 295-336.

Chin, Wynne W. 2010. How to Write Up and Report PLS Analyses Handbook of Partial least Squares. Berlin/Heidelberg: Springer, pp. 655-90.

Cohen, Jacob. 1988. Statistical Power Analysis for the Behavioral Sciences. Hillsdale: Lawrence Erlbaum Associates.

Costa, Victoria. 2018. Patriotism and Nationalism International Handbook of Philosophy of Education. Berlin/Heidelberg: Springer, pp. $1389-400$.

Crocker, Keith J., and Joel Slemrod. 2005. Corporate tax evasion with agency costs. Journal of Public Economics 89: 1593-610. [CrossRef]

Cullis, John G., and Alan Lewis. 1997. Why people pay taxes: From a conventional economic model to a model of social convention. Journal of Economic Psychology 18: 305-21. [CrossRef]

Damayanti, Theresia Woro. 2012. Changes on Indonesia Tax Culture, Is there a way? Studies through theory of planned behavior. Researchers World 3: 8.

Das-Gupta, Arindam, and Ira Gang. 2003. Value added tax evasion, auditing and transactions matching. In Institutional Elements of Tax Design and Reform. Edited by John Maclarn. Washington, DC: The World Bank, pp. 25-48.

Devos, Ken. 2013. Do penalties and enforcement measures make taxpayers more compliant? The view of Australian tax evaders. Far East Journal of Psychology and Business 12: 1-9.

Dobrowolska, Bogusława. 2008. Value Added Tax in European Union Countries-Comparative Analysis. Available online: https: // dspace.uni.lodz.pl/bitstream/handle/11089/7635/78-93.pdf?sequence=1\&isAllowed=y (accessed on 10 October 2021).

Doerrenberg, Philipp. 2015. Does the use of tax revenue matter for tax compliance behavior? Economics Letters 128: 30-34. [CrossRef]

Druckman, Daniel. 1994. Nationalism, patriotism, and group loyalty: A social psychological perspective. Mershon International Studies Review 38: 43-68. [CrossRef] 
Elliott, Mark A., Christopher J. Armitage, and Christopher J. Baughan. 2005. Exploring the beliefs underpinning drivers' intentions to comply with speed limits. Transportation Research Part F: Traffic Psychology and Behaviour 8: 459-79. [CrossRef]

Eriksen, Knut, and Lars Fallan. 1996. Tax knowledge and attitudes towards taxation; A report on a quasi-experiment. Journal of Economic Psychology 17: 387-402. [CrossRef]

Faridy, Nahida, Brett Freudenberg, Tapan Sarker, and Richard Copp. 2016. The hidden compliance cost of VAT: An exploration of psychological and corruption costs of VAT in a developing country. eJTR 14: 166.

Fischer, Carol, Martha Wartick, and Melvin Mark. 1992. Detection probability and taxpayer compliance: A review of the literature. Journal of Accounting Literature 11: 1.

Fishbein, Martin, and Icek Ajzen. 1974. Attitudes towards objects as predictors of single and multiple behavioral criteria. Psychological Review 81: 59.

Fishbein, Martin, and Icek Ajzen. 1975a. Belief, Attitude, Intention and Behavior: An Introduction to Theory and Research. Reading: Addison-Wesley, p. 578.

Fishbein, Martin, and Icek Ajzen. 1975b. Intention and Behavior: An Introduction to Theory and Research. Reading: Addison-Wesley.

Fishbein, Martin, James Jaccard, Andrew R. Davidson, Icek Ajzen, and Barbara Loken. 1980. Predicting and Understanding Family Planning Behaviors Understanding Attitudes and Predicting Social Behavior. Hoboken: Prentice Hall.

Fuest, Clemens, and Nadine Riedel. 2009. Tax Evasion, Tax Avoidance and Tax Expenditures in Developing Countries: A Review of the Literature. London: UK Department for International Development, p. 44.

Gangl, Katharina, Benno Torgler, and Erich Kirchler. 2016. Patriotism's impact on cooperation with the state: An experimental study on tax compliance. Political Psychology 37: 867-81. [CrossRef]

Geisser, Seymour. 1974. A predictive approach to the random effect model. Biometrika 61: 101-7. [CrossRef]

Gentry, Lance, and Roger Calantone. 2002. A comparison of three models to explain shop-bot use on the web. Psychology $\mathcal{E}$ Marketing 19: $945-56$

George, Reji, and Y. V. Reddy. 2015. Corporate tax in emerging countries: Some aspects of India. International Journal of Law and Management 57: 357-66. [CrossRef]

Giesecke, James, and Nhi Hoang Tran. 2012. A general framework for measuring VAT compliance rates. Applied Economics 44: 1867-89. [CrossRef]

Goh, Beng Wee, Jimmy Lee, Chee Yeow Lim, and Terry Shevlin. 2016. The effect of corporate tax avoidance on the cost of equity. The Accounting Review 91: 1647-70. [CrossRef]

Haddad, Ayman E., Wafaa M. Sbeiti, and Amer Qasim. 2017. Accounting legislation, corporate governance codes and disclosure in Jordan: A review. International Journal of Law and Management 59: 147-76. [CrossRef]

Hair, Joe F., Christian M. Ringle, and Marko Sarstedt. 2013. Partial least squares structural equation modeling: Rigorous applications, better results and higher acceptance. Long Range Planning 46: 1-12. [CrossRef]

Hair, Joseph F., Jeffrey J. Risher, Marko Sarstedt, and Christian M. Ringle. 2019. When to use and how to report the results of PLS-SEM. European Business Review 31: 2-24. [CrossRef]

Hair, Joe F., Jr., Matt C. Howard, and Christian Nitzl. 2020. Assessing measurement model quality in PLS-SEM using confirmatory composite analysis. Journal of Business Research 109: 101-10. [CrossRef]

Hair, Joseph F., Jr., Marko Sarstedt, Christian M. Ringle, and Siegfried P. Gudergan. 2017. Advanced Issues in Partial Least Squares Structural Equation Modeling. Thousand Oaks: Sage Publications.

Hair, Joe F., Jr., Marko Sarstedt, Lucas Hopkins, and Volker G. Kuppelwieser. 2014. Partial least squares structural equation modeling (PLS-SEM). European Business Review 26: 106-21. [CrossRef]

Hamid, Suhaila Abdul. 2014. Tax Compliance Behaviour of Tax Agents: A Comparative Study of Malaysia and New Zealand. Ph.D. thesis, University of Canterbury, Christchurch, New Zealand.

Hanno, Mor, and Goerg Violette. 1996. An Analysis of Moral and Social Compliance on Taxpayer Behaviour. Behavioural Research in Accounting 8: 57-79.

Hansford, Ann, and John Hasseldine. 2012. Tax compliance costs for small and medium sized enterprises: The case of the UK. eJTR 10: 288 .

Hansford, Ann, John Hasseldine, and Carole Howorth. 2003. Factors affecting the costs of UK VAT compliance for small and medium-sized enterprises. Environment and Planning C: Government and Policy 21: 479-92. [CrossRef]

Henseler, Jörg, Christian M. Ringle, and Rudolf R. Sinkovics. 2009. The Use of Partial Least Squares Path Modeling in International Marketing New Challenges to International Marketing. Bingley: Emerald Group Publishing Limited.

Hite, Peggy, and Michael L. Roberts. 1992. An analysis of tax reform based on taxpayers' perceptions of fairness and self-interest. Advances in Taxation 4: 115-37.

Huang, Jason, and Juan Rios. 2016. Optimal tax mix with income tax non-compliance. Journal of Public Economics 144: 52-63. [CrossRef]

Israel, Glenn. 1992. Determining Sample Size. Gainesville: Institute of Food and Agriculture Sciences, University of Florida Cooperative Extension Service.

Jackson, Betty, and Valerie Milliron. 1986. Tax compliance research: Findings, problems, and prospects. Journal of Accounting Literature 5: $125-65$.

Jayawardane, Damayanthi. 2015. Psychological factors affect tax compliance-a review paper. International Journal of Arts and Commerce 4: 131-41. 
Kahne, Joseph, and Ellen Middaugh. 2006. Is patriotism good for democracy? A study of high school seniors' patriotic commitments. Phi Delta Kappan 87: 600-7. [CrossRef]

Kahne, Joseph, Bernadette Chi, and Ellen Middaugh. 2006. Building social capital for civic and political engagement: The potential of high-school civics courses. Canadian Journal of Education/Revue Canadienne de L'éducation 29: 387-409. [CrossRef]

Kamleitner, Bernadette, Christian Korunka, and Erich Kirchler. 2012. Tax compliance of small business owners. International Journal of Entrepreneurial Behavior \& Research 18: 330-51.

Keen, Michael, and Stephen Smith. 2007. VAT Fraud and Evasion: What Do We Know, and What Can Be Done? IMF Working Papers. Washington, DC: International Monetary Fund, pp. 1-33.

Kirchler, Erich. 2007. The Economic Psychology of Tax Behaviour. Cambridge: Cambridge University Press.

Kirchler, Erich, Erik Hoelzl, and Ingrid Wahl. 2008. Enforced versus voluntary tax compliance: The "slippery slope" framework. Journal of Economic Psychology 29: 210-25. [CrossRef]

Konrad, Kai A., and Salmai Qari. 2012. The last refuge of a scoundrel? Patriotism and tax compliance. Economica 79: 516-33. [CrossRef]

Kornhauser, Marjorie. 2007. Normative and cognitive aspects of tax compliance: Literature review and recommendations for the IRS regarding individual taxpayers. Florida Tax Review 8: 601-34.

Krejcie, Robert, and Daryle Morgan. 1970. Determining sample size for research activities. Educational and Psychological Measurement 30: 607-10. [CrossRef]

Kuria, John, Bernard Omboi, and George Achoki. 2017. Effect of corporate income tax incentive on the performance of EPZ firms in Kenya. International Journal of Finance and Accounting 2: 43-55. [CrossRef]

Langham, Jo'Anne, Neil Paulsen, and Charmine EJ Hartel. 2012. Improving tax compliance strategies: Can the theory of planned behaviour predict business compliance. eJTR 10: 364.

Lee, Dongwon, Dongil Kim, and Thomas E. Borcherding. 2013. Tax structure and government spending: Does the value-added tax increase the size of government? National Tax Journal 66: 541-70. [CrossRef]

Letirand, Frédéric, and Patricia Delhomme. 2005. Speed behaviour as a choice between observing and exceeding the speed limit. Transportation Research Part F: Traffic Psychology and Behaviour 8: 481-92. [CrossRef]

Lignier, Philip, and Chris Evans. 2012. The rise and rise of tax compliance costs for the small business sector in Australia. Australian Tax Forum 27: 615-72.

Lutf, Abd Alwali, and Rosli Mohamad. 2016. The influence of technological, organizational and environmental factors on accounting information system usage among Jordanian small and medium-sized enterprises. International Journal of Economics and Financial Issues 6: 240-48.

Lutfi, Abdalwali. 2020. Investigating the Moderating Role of Environmental Uncertainty between Institutional Pressures and ERP Adoption in Jordanian SMEs. Journal of Open Innovation: Technology, Market, and Complexity 6: 91. [CrossRef]

Lutfi, Abdalwali. 2017. Antecedents and Impact of AIS Usage Amongst Jordanian SMEs: Moderating Effects of Environmental Uncertainty and Firm Size. Bukit Kayu Hitam: Universiti Utara Malaysia.

Lutfi, Abdalwali, Kamil Md Idris, and Rosli Mohamad. 2017. AIS usage factors and impact among Jordanian SMEs: The moderating effect of environmental uncertainty. Journal of Advanced Research in Business and Management Studies 6: 24-38.

MacGregor, Jason, and Brett Wilkinson. 2012. The Effect of Economic Patriotism on Tax Morale and Attitudes toward Tax Compliance Advances in Taxation. Bingley: Emerald Group Publishing Limited.

Marandu, Edward E., Christian J. Mbekomize, and Alexander N. Ifezue. 2015. Determinants of tax compliance: A review of factors and conceptualizations. International Journal of Economics and Finance 7: 207-18. [CrossRef]

Maseko, Nelson. 2014. Determinants of tax compliance by small and medium enterprises in Zimbabwe. Journal of Economics and International Business Research 2: 48-57. [CrossRef]

Molero, Juan Carlos, and Francesc Pujol. 2012. Walking inside the potential tax evader's mind: Tax morale does matter. Journal of Business Ethics 105: 151-62. [CrossRef]

Nguyen, Tan H. 2017. Determinants to Tax Evasion Behavior in Vietnam. Journal of Management and Sustainability 7: 123. [CrossRef]

Nsour, Maen. 2014. Tax evasion in Jordan: Causes, means and size. The Jordan Times 3: 2014.

Nur-Tegin, Kanybek. 2008. Determinants of business tax compliance. The B.E. Journal of Economic Analysis E Policy 8: 1. [CrossRef]

Ochulor, Chinenye Leo. 2011. Ethical and moral implications of corruption. Canadian Social Science 7: 223-28.

Onu, Diana. 2016. Measuring Tax Compliance Attitudes: What Surveys Can Tell Us about Tax Compliance Behaviour Advances in Taxation. Bingley: Emerald Group Publishing Limited.

Qari, Salmai, Kai A. Konrad, and Benny Geys. 2012. Patriotism, taxation and international mobility. Public Choice 151: 695-717. [CrossRef]

Ramli, Rosiati, Mohd Rizal Palil, Norul Syuhada Abu Hassan, and Ahmad Fariq Mustapha. 2015. Compliance costs of Goods and Services Tax (GST) among small and medium enterprises. Jurnal Pengurusan (UKM Journal of Management) 45: 39-48. [CrossRef]

Randlane, Kerly. 2016. Tax compliance as a system: Mapping the field. International Journal of Public Administration 39: 515-25. [CrossRef]

Rhodes, Ryan, Chris Blanchard, Deborah Hunt Matheson, and James Coble. 2006. A multicomponent model of the theory of planned behaviour. British Journal of Health Psychology 11: 119-37. [CrossRef]

Richardson, Grant. 2006. Determinants of tax evasion: A cross-country investigation. Journal of International Accounting, Auditing and Taxation 15: 150-69. [CrossRef] 
Richardson, Maryann, and Adrian J. Sawyer. 2001. A taxonomy of the tax compliance literature: Further findings, problems and prospects. Australian Taxation Forms 16: 137.

Ringle, Christian, Marko Sarstedt, and Detmar Straub. 2012. Editor's Comments: A Critical Look at the Use of PLS-SEM in "MIS Quarterly". MIS Quarterly 36: iii-xiv. [CrossRef]

Robben, Henry, Paul Webley, Henk Elffers, and Dick Hessing. 1990. Decision frames, opportunity and tax evasion: An experimental approach. Journal of Economic Behavior \& Organization 14: 353-61.

Roberts, Michael. 1994. An experimental approach to changing taxpayers' attitudes towards fairness and compliance via television. The Journal of the American Taxation Association 16: 67.

Roth, Jeffrey, John Scholz, and Ann Witte. 1989. Taxpayer Compliance: An Agenda for Research. Philadelphia: University of Pennsylvania Press, vol. 1.

Saad, Natrah. 2011. Fairness Perceptions and Compliance Behaviour: Taxpayers' Judgments in Self-Assessment Environments. Christchurch: University of Canterbury.

Saad, Natrah. 2012. Tax non-compliance behaviour: Taxpayers view. Procedia-Social and Behavioral Sciences 65: 344-51. [CrossRef]

Sandmo, Agnar. 2005. The theory of tax evasion: A retrospective view. National Tax Journal 58: 643-63. [CrossRef]

Sattler, Henrik, Franziska Völckner, Claudia Riediger, and Christian Ringle. 2010. The impact of brand extension success drivers on brand extension price premiums. International Journal of Research in Marketing 27: 319-28. [CrossRef]

Sarstedt, Marko, Christian Ringle, Jörg Henseler, and Joseph Hair. 2014. On the emancipation of PLS-SEM: A commentary on Rigdon 2012. Long Range Planning 47: 154-60. [CrossRef]

Scholz, John Karl. 1994. The earned income tax credit: Participation, compliance, and antipoverty effectiveness. National Tax Journal 47: 63-87. [CrossRef]

Sekaran, Uma, and Roger Bougie. 2003. Research Methods for Business, a Skill Building Approach. New York: John Willey \& Sons.

Slemrod, Joel. 2007. Cheating ourselves: The economics of tax evasion. Journal of Economic Perspectives 21: 25-48. [CrossRef]

Smart, Martha. 2012. The Application of the Theory of Planned Behaviour and Structural Equation Modelling in Tax Compliance Behaviour: A New Zealand Study. Christchurch: University of Canterbury.

Stone, Mervyn. 1974. Cross-validation and multinomial prediction. Biometrika 61: 509-15. [CrossRef]

Świstak, Artur, Sebastian Wawrzak, and Agnieszka Alińska. 2015. In pursuit of tax equity: Lessons from VAT rate structure adjustment in Poland. Financial Theory and Practice 39: 115-37. [CrossRef]

Tajfel, Henri. 1974. Social identity and intergroup behaviour. Information (International Social Science Council) 13: 65-93. [CrossRef]

Torgler, Benno. 2002. Does culture matter? Tax morale in an East-West-German comparison. FinanzArchiv/Public Finance Analysis 59: 504-28. [CrossRef]

Torgler, Benno. 2005. Tax morale and direct democracy. European Journal of Political Economy 21: 525-31. [CrossRef]

Torgler, Benno. 2007. Tax Compliance and Tax Morale: A Theoretical and Empirical Analysis. Cheltenham: Edward Elgar Publishing.

Trivedi, Viswanath Umashanker, Mohamed Shehata, and Stuart Mestelman. 2005. Attitudes, incentives, and tax compliance. Canadian Tax Journal 53: 29.

Tsakumis, George, Anthony Curatola, and Thomas Porcano. 2007. The relation between national cultural dimensions and tax evasion. Journal of International Accounting, Auditing and Taxation 16: 131-47. [CrossRef]

Wadesango, Newman, and Gift Chirebvu. 2020. The impact of Value Added Tax (VAT) on small and medium enterprises in a developing country. Academy of Accounting and Financial Studies Journal 24: 1-12.

Widuri, Retnaningtyas, Devina Devina, Fransiska Marta, and Yulia Wati. 2019. The Influence of Penalties, the Trust on Authorities, and the Tax Audit Toward Tax Compliance. Journal of Economics and Business 2: 2. [CrossRef]

Witte, Ann, and Diane Woodbury. 1985. The effect of tax laws and tax administration on tax compliance: The case of the US individual income tax. National Tax Journal 38: 1-13. [CrossRef]

Woodward, Lynley, and Lin Mei Tan. 2015. Small business owners' attitudes toward GST compliance: A preliminary study. Australian Taxation Forms 30: 517. [CrossRef]

Wright, Alexandra, Katherine Smith, and Mark Hellowell. 2017. Policy lessons from health taxes: A systematic review of empirical studies. BMC Public Health 17: 583. [CrossRef]

Wynter, Carlene Beth. 2014. Property Tax Administration in Practice: A Case Study of the Portmore Municipality, Jamaica. Ph.D. thesis, University of Exeter, Exeter, UK.

Ya'u, Abba, Natrah Saad, and Abdulsalam Mas'ud. 2020. Effects of economic deterrence variables and royalty rates on petroleum profit tax compliance in Nigeria: An empirical analysis. International Journal of Energy Sector Management 14: 1275-96. [CrossRef]

Yitzhaki, Shlomo. 1974. A Note on Income Tax Evasion: A Theoretical Analysis. Journal of Public Economics 3: 201-2. [CrossRef]

Yucedogru, Recep, and John Hasseldine. 2016. Understanding tax morale of SMEs: A qualitative study. eJTR 14: 531.

Yusof, Nor Azrina Mohd, and Ming Ling Lai. 2014. An integrative model in predicting corporate tax fraud. Journal of Financial 21: $424-32$

Zikmund, William G., Jon C. Carr, and Mitch Griffin. 2013. Business Research Methods (Book Only). Boston: Cengage Learning. 